\title{
Inactivation of $\Delta^{5}$-3-oxo steroid isomerase with active-site-directed acetylenic steroids
}

\author{
Trevor M. PENNING, ${ }^{*}$ Douglas F. COVEY $\dagger$ and Paul TALALAY* \\ *Department of Pharmacology and Experimental Therapeutics, The Johns Hopkins University School of \\ Medicine, Baltimore, MD 21205, U.S.A., and †Department of Pharmacology, Washington University School \\ of Medicine, St. Louis, MO 63110, U.S.A.
}

\section{(Received 2 June 1980/Accepted 18 August 1980)}

\begin{abstract}
Several steroid analogues containing conjugated acetylenic ketone groups as part of a seco-ring structure or as substituents on the intact steroid system are irreversible inhibitors of $\Delta^{5}$-3-oxo steroid isomerase (EC 5.3.3.1) from Pseudomonas testosteroni. Thus 10 $\beta$-(1-oxoprop-2-ynyl)oestr-4-ene-3,17-dione (I), 5,10-seco-oestr-4-yne-3,10,17trione (II), 17 $\beta$-hydroxy-5,10-seco-oestr-4-yne-3,10-dione (III) and 17 $\beta$-(1-oxoprop2-ynyl)androst-4-en-3-one (IV) irreversibly inactivate isomerase in a time-dependent manner. In all cases saturation kinetics are observed. Protection against inactivation is afforded by the powerful competitive inhibitor 19-nortestosterone. The inhibition constants $\left(K_{\mathrm{i}}\right)$ for 19-nortestosterone obtained from such experiments are in good agreement with those determined from conventional competitive-inhibition studies of enzyme activity. These compounds thus appear to be active-site directed. In every case the inactivated enzyme could be dialysed without return of activity, indicating that a stable covalent bond probably had formed between the steroid and enzyme. Compound (I) is a very potent inhibitor of isomerase $\left[K_{\mathrm{i}}=66.0 \mu \mathrm{M}\right.$ and $k_{+2}=12.5 \times 10^{-3} \mathrm{~s}^{-1}$ (where $K_{1}$ is the dissociation constant of the reversible enzyme-inhibitor complex and $k_{+2}$ is the rate constant for the inactivation reaction of the enzyme-inhibitor complex)] giving half-lives of inactivation of $30-45 \mathrm{~s}$ at saturation. It is argued that the basic-amino-acid residue that abstracts the intramolecularly transferred $4 \beta$-proton in the reaction mechanism could form a Michael-addition product with compound (I). In contrast, although compound (IV) has a lower inhibition constant $\left(K_{\mathrm{f}}=14.5 \mu \mathrm{M}\right)$, it is a relatively poor alkylating agent $\left(k_{+2}=0.13 \times 10^{-3} \mathrm{~s}^{-1}\right)$. If the conjugated acetylenic ketone groups are replaced by $\alpha$-hydroxyacetylene groups, the resultant analogues of steroids (I)-(IV) are reversible competitive inhibitors with $K_{\mathrm{f}}$ values in the range 27-350 $\mu \mathrm{M}$. The enzyme binds steroids in the $C_{19}$ series with functionalized acetylenic substituents at $\mathrm{C}-17$ in preference to steroids in the $\mathrm{C}_{18}$ series bearing similar groups in the ring structure or as $\mathrm{C}-10$ substituents. In the 5,10-seco-steroid series the presence of hydroxy groups at both $\mathrm{C}-3$ and $\mathrm{C}-17$ is deleterious to binding by the enzyme.
\end{abstract}

$\Delta^{5}$-3-Oxo steroid isomerase (EC 5.3.3.1) from Pseudomonas testosteroni is to our knowledge the only homogeneous and crystalline enzyme of steroid metabolism (Kawahara \& Talalay, 1960; Kawahara et al., 1962), which is of known amino-acid sequence (Benson et al., 1971) and is under study by X-ray crystallography (Westbrook, 1976; Westbrook et al., 1976). The enzyme catalyses the conversion of $\Delta^{5}$-3-oxo steroids to $\Delta^{4}$-3-oxo steroids by a mechanism believed to involve combined acid-base catalysis in which the base effects the intramolecular transfer of the $4 \beta$-proton to the $6 \beta$-position as shown in Scheme 1 (Malhotra \& Ringold, 1965; Talalay \&
Benson, 1972). Several attempts have been made to label the active site of the enzyme by affinity reagents (Büki et al., 1971; Batzold \& Robinson, 1975; Ogez et al., 1977; Pollack et al., 1979). The most elegant approach to this problem is that described by Robinson and his colleagues, who have synthesized two acetylenic seco-steroids, namely 5,10-seco-oestr-4-yne-3,10,17-trione (X) and 19nor-5,10-secopregn-5-yne-3,10,20-trione (XI) (Batzold \& Robinson, 1976). These compounds inactivate isomerase irreversibly in a time-dependent manner (Batzold \& Robinson, 1975). They are converted at the active site by the normal catalytic 


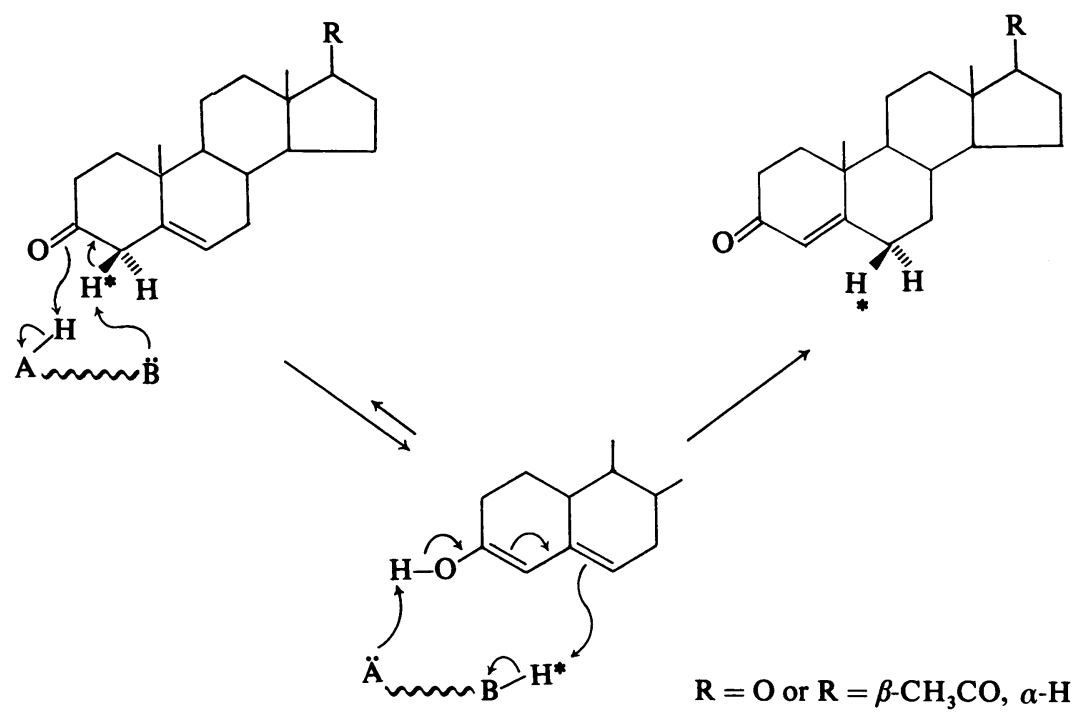

Scheme 1. Mechanistic pathway for enzyme-catalysed isomerization of $\Delta^{5}$-3-oxo steroids to $\Delta^{4}-3$-oxo steroids The enzymic isomerization is promoted by acid (AH) and base (B) catalysis at the active site. The base (B) abstracts the $4 \beta$-proton $\left(\mathrm{H}^{*}\right)$, which is transferred intramolecularly to the $6 \beta$-position. The $\Delta^{3,5}$-dienol is a postulated intermediate.

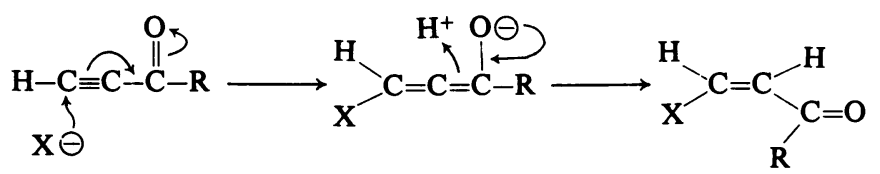

Scheme 2. Nucleophilic addition to an $\alpha \beta$-acetylenic ketone A nucleophile $(\mathrm{X})$ can alkylate the $\beta$-carbon of an $\alpha \beta$-acetylenic ketone. Nucleophilic attack is facilitated by enolization.

mechanism of isomerase into the corresponding highly reactive conjugated allenic ketones (Covey \& Robinson, 1976), which are thus in a unique position to alkylate a reactive nucleophile, presumably the base involved in catalysis.

Several $C_{18}$ and $C_{19}$ steroids bearing either oxopropynyl or hydroxypropynyl groups as part of the ring structure or as substituents on the steroid skeleton have been synthesized (Covey, 1979; Covey et al., 1979b). Steroids in the $C_{19}$ series bearing a hydroxypropynyl group at $\mathrm{C}-17$ and steroids in the $\mathrm{C}_{18}$ series containing a hydroxypropynyl group at C-10 are of particular interest since these compounds presumably could be oxidized by $20 \beta$-hydroxy steroid dehydrogenase or by steroid aromatase respectively to the corresponding conjugated acetylene system. The enzyme-generated conjugated acetylenic ketone would then be in a position to be a very selective inhibitor of either of these enzymes, whereas the precursor hydroxy- propynyl steroids would fall into the general category of steroid suicide substrates. An extension of this work would be to examine the ability of these oxopropynyl steroids to act as general affinity labelling reagents for steroid-transforming enzymes, since the conjugated acetylenic ketones should undergo facile attack by a nucleophile at the active site to form a Michael addition product (Scheme 2).

The present paper describes a series of oxopropynyl steroids that act as active-site-directed irreversible inhibitors of $\Delta^{5}$-3-oxo steroid isomerase from $P$. testosteroni and a series of hydroxypropynyl steroids that act as competitive inhibitors of the same enzyme. This is of particular interest, since it is possible that the nucleophile available for alkylation by several oxopropynyl steroids is the base involved in catalysis. The results reported in the present paper emphasize the importance of extending these studies to mammalian steroid isomerases, and the possibility that both the hydroxy- and 
oxopropynyl compounds may modify steroid metabolism.

\section{Materials and methods}

\section{Materials}

Spectroscopic-quality acetonitrile was obtained from Burdick and Jackson, Muskegon, MI, U.S.A., and crystalline bovine serum albumin from Armour Pharmaceuticals, Chicago, IL, U.S.A. Solutions of albumin were neutralized with $\mathrm{NaOH}$.

Crystalline isomerase (sp. activity $52000 \mu \mathrm{mol}$ of androst-5-ene-3,17-dione isomerized/min per $\mathrm{mg}$ ) was prepared and assayed by our standard procedures (Wang et al., 1963; Jarabak et al., 1969; Benson et al., 1974). Specific activities were based on protein concentrations determined from an extinction coefficient of $A_{1 \mathrm{~cm}}^{0.1 \%}$ at $280 \mathrm{~nm}$ of 0.336 (Benson et al., 1975). The molarities of enzyme solutions were expressed in terms of the subunit molecular weight of 13394 (Benson et al., 1971).

Androst-5-ene-3,17-dione and pregn-5-ene-3,20dione were synthesized from dehydroepiandrosterone and pregnenolone respectively (Kawahara, 1962). 19-Nortestosterone was purified by crystallization and high-vacuum sublimation. 10 $\beta$-(1Oxoprop-2-ynyl)oestr-4-ene-3,17-dione (I), 17 $\beta$-(1oxoprop-2-ynyl)androst-4-en-3-one (IV), $10 \beta$-[(1R)1-hydroxyprop-2-ynylloestr-4-ene-3,17-dione (V), $10 \beta$-[(1S)-1-hydroxyprop-2-ynyl] oestr-4-ene-3,17dione (VI), 17 $\beta$-[(1R)-1-hydroxyprop-2-ynyl $]-$ androst-4-en-3-one (VII) and $17 \beta$-[(1S)-1-hydroxyprop-2-ynyl]androst-4-en-3-one (VIII) were prepared as described previously (Covey, 1979; Covey et al., 1979b). 5,10-Seco-oestr-4-yne-3,10,17-trione (II), $17 \beta$-hydroxy-5,10-seco-oestr-4-yne-3,10-dione (III) and $3 \beta, 17 \beta$-dihydroxy-5,10-seco-oestr-4-yn-10one (IX) were also synthesized (D. F. Covey \& V. D. Parikh, unpublished work). The syntheses of 5,10-seco-oestr-5-yne-3,10,17-trione (X) and 19nor-5,10-seco-pregn-5-yne-3,10,20-trione (XI) have been reported (Batzold \& Robinson, 1976) and samples of these compounds were gifts from C. $\mathrm{H}$. Robinson. When appropriate, the identity, purity and concentration of steroid solutions were checked by u.v. spectroscopy.

\section{Inactivation experiments}

The inactivation of isomerase was studied at $25^{\circ} \mathrm{C}$ in systems of $0.25-1.0 \mathrm{ml}$ final volume containing $1.0 \mathrm{~mm}$-potassium phosphate buffer, $\mathrm{pH} 7.0,2.0 \mu \mathrm{M}$ enzyme, and various concentrations of steroids in acetonitrile (4 or $8 \%, v / v)$. Incubations were started by the addition of the steroid solution. Portions $(1 \mu \mathrm{l})$ were removed at suitable time intervals, diluted 1000 -fold with $1 \%$ bovine serum albumin and assayed for enzyme activity (Wang $e t$ al., 1963). When a semi-logarithmic plot of the percentage of activity remaining with respect to time declined in a linear manner, indicating pseudofirst-order inactivation, the results were analysed further by the method of Kitz \& Wilson (1962). In this method, it is assumed that $[\mathrm{I}] \gg[\mathrm{E}]$, that EI (the reversible enzyme-inhibitor complex) is at all times in equilibrium with enzyme and inhibitor, and that many reversible enzyme-inhibitor complexes form before one molecule of enzyme is inactivated (i.e. $\left.k_{+2} \ll k_{-1}\right)$ :

$$
\mathrm{E}+\mathrm{I} \underset{k_{-1}}{\stackrel{k_{+1}}{\rightleftharpoons}} \mathrm{EI} \stackrel{k_{+2}}{\longrightarrow} \mathrm{E}^{*}
$$

where $\mathrm{E}^{*}$ is the inactivated enzyme, $k_{-1} / k_{+1}$ is $K_{\mathrm{i}}$ (the dissociation constant of the enzyme-inhibitor complex) and $k_{+2}$ becomes the rate constant for the inactivation reaction within the enzyme-inhibitor complex. It has been demonstrated that this condition of quasi-equilibrium holds when the value of the apparent second-order rate constant for the inactivation of the enzyme is much smaller than $k_{+1}$ (Brocklehurst, 1979). In our experiments the values of $k_{+2} / K_{1}$ are well below $1 \times 10^{6} \mathrm{M}^{-1} \cdot \mathrm{s}^{-1}$, whereas $k_{+1}$ is commonly at least $10^{7} \mathrm{M}^{-1} \cdot \mathrm{s}^{-1}$ for substrates.

By taking the reciprocals of the apparent pseudofirst-order rate constants of inactivation $\left(1 / k_{\text {app. }}\right)$ and plotting them against the reciprocal of the inhibitor concentration (1/[I]) for a series of values of [I], a linear relationship is obtained from which both $K_{1}$ and $k_{+2}$ can be determined (Kitz \& Wilson, 1962), since:

$$
\frac{1}{k_{\text {app. }}}=\frac{1}{k_{+2}}+\frac{K_{\mathrm{i}}}{k_{+2}[\mathrm{I}]}
$$

This relationship has the same form as the Lineweaver-Burk transformation of the MichaelisMenten equation (Lineweaver \& Burk, 1934):

$$
\frac{1}{v}=\frac{1}{V_{\max .}}+\frac{K_{\mathrm{m}}}{V_{\max .}[\mathrm{S}]}
$$

Incubations of isomerase in the presence of acetonitrile and buffer under the above conditions resulted in no significant loss of enzyme activity over the period of duration of the experiments. In nearly all instances, the steroids were stable in $1 \mathrm{mM}$ potassium phosphate buffer at $\mathrm{pH}$ 7.0. However, compounds (X) and (XI) are only moderately stable under such conditions, and are transformed via the conjugated allenic ketones to the corresponding 3,5-diketones (Covey et al., 1979a; T. M. Penning, D. F. Covey \& P. Talalay, unpublished work). The rates of formation of these non-enzymic products are sufficiently low to introduce only minor errors in the measurements of the rates of inactivation.

\section{Protection by 19-nortestosterone}

Protection of isomerase against irreversible inactivation by compounds (I-IV) and (X) was afforded 
by 19-nortestosterone, a powerful competitive inhibitor of the enzyme (Wang et al., 1963). This phenomenon was studied under conditions described above with a constant amount of irreversible inhibitor and various concentrations of 19. nortestosterone. The incubations were initiated by the addition of the enzyme. Portions $(1 \mu \mathrm{l})$ were removed at specified time intervals, diluted 1000 -fold with $1 \%$ bovine serum albumin and assayed for enzyme activity. The final concentration of 19 nortestosterone in the assay system had a negligible effect on the velocity. A semi-logarithmic plot of the percentage of enzyme activity remaining with respect to time was constructed for each 19nortestosterone concentration. Pseudo-first-order rate constants of inactivation $\left(k_{\text {app. }}\right)$ were obtained and a secondary plot of $1 / k_{\text {app. }}$ versus 19 nortestosterone concentration $\left(\left[I^{\prime}\right]\right)$ was made. This plot, which is analogous to the Dixon plot $(1 / v$ against [I]; Dixon, 1953) for reversible inhibitors, permits the calculation of $K_{1}$ values for 19nortestosterone (designated here as $K_{1}{ }^{\prime}$ ), on the assumption of competitive inhibition. The slope of the Dixon plot is given by $K_{\mathrm{m}} /\left(V_{\max } K_{\mathrm{t}}[\mathrm{S}]\right)$, whereas the slope of the plot of $1 / k_{\text {app. }}$ with respect to $\left[I^{\prime}\right]$ is $K_{1} /\left(k_{+2} K_{1}^{\prime}[\mathrm{I}]\right)$, as may be seen by comparison of eqns. (1) and (2).

\section{Competitive inhibition studies}

Initial velocities of isomerization of either of the natural substrates pregn-5-ene-3,20-dione or androst-5-ene-3,17-dione were measured in a system containing $2.7 \mathrm{ml}$ of water, $0.1 \mathrm{ml}$ of $1 \mathrm{M}$-potassium phosphate buffer, $\mathrm{pH} 7.0$, the steroid inhibitor in $200 \mu 1$ of acetonitrile and $10 \mu 1$ of $1 \%$ bovine serum albumin. The reaction was followed by measuring the formation of the $\Delta^{4}$-3-oxo steroid $\left(\lambda_{\max .}=\right.$ $\left.248 \mathrm{~nm} ; \varepsilon=16300 \mathrm{M}^{-1} \cdot \mathrm{cm}^{-1}\right)$. Non-enzymic rates were measured over $5 \mathrm{~min}$ and subtracted from the enzymic rate. The non-enzymic rate was found to be less than $4 \%$ of that of the enzyme-catalysed reaction. In all cases the reaction was started by addition of enzyme.

In every experiment the $K_{\mathrm{m}}$ and $V_{\max }$ values for the natural substrates were determined over the concentration range $0-25 \mu \mathrm{M}$ for pregn-5-ene-3,20dione and $0-250 \mu \mathrm{M}$ for androst-5-ene-3,17-dione (the upper concentrations approach the limits of solubility). The effect of a range of inhibitor concentrations was examined for each of three to five substrate concentrations. For $\mathrm{C}_{19}$-steroids bearing a 1-hydroxyprop-2-ynyl substituent at $\mathrm{C}-17$ the concentration of inhibitor was varied from 0 to $25 \mu \mathrm{M}$. For steroids in the $\mathrm{C}_{18}$ series bearing an $\alpha$-hydroxyacetylene group either in the ring structure or as a substituent, concentrations of inhibitor between 0 and $200 \mu \mathrm{M}$ were used. Dixon plots were then constructed for at least three substrate con- centrations and the slope of each line was used to construct a secondary plot (i.e. slope of Dixon plot against $1 /[\mathrm{S}]$ ) from which the $K_{1}$ values were computed. In all cases the lines were drawn by linear regression analysis.

\section{Dialysis experiments}

Inactivated isomerase obtained from the various experiments (containing less than $2 \%$ of the initial activity) was diluted to $1.0 \mathrm{ml}$ and dialysed for $24 \mathrm{~h}$ against three changes of 1 litre of $1 \mathrm{~mm}$-potassium phosphate, $\mathrm{pH}$ 7.0. At the end of the dialysis a portion of the enzyme was diluted 1000 -fold with $1 \%$ bovine serum albumin and assayed for enzyme activity under standard conditions. Isomerase that was incubated in the absence of steroid can be dialysed under identical conditions without loss of enzyme activity.

\section{Results}

The following compounds were found to be active-site-directed irreversible inhibitors of $\Delta^{5}$-3-oxo steroid isomerase from $P$. testosteroni: $10 \beta-(1-$ oxoprop-2-ynyl)oestr-4-ene-3,17-dione (I), 5,10seco-oestr-4-yne-3,10,17-trione (II), 17 $\beta$-hydroxy5,10-seco-oestr-4-yne-3,10-dione (III) and $17 \beta$-(1oxoprop-2-ynyl)androst-4-en-3-one (IV). In addition the following compounds were found to be competitive inhibitors: $10 \beta-[(1 R)-1$-hydroxyprop2-ynyl]oestr-4-ene-3,17-dione (V), 10 $\beta$-[(1S)-1hydroxyprop-2-ynylloestr-4-ene-3,17-dione (VI), $17 \beta$-[(1R)-1-hydroxyprop-2-ynyl]androst-4-en-3-one (VII), $17 \beta$-[(1S)-1-hydroxyprop-2-ynyl]androst-4en-3-one (VIII) and $3 \beta, 17 \beta$-dihydroxy-5,10-secooestr-4-yn-10-one (IX).

\section{0ß-(1-Oxoprop-2-ynyl)oestr-4-ene-3,17-dione (I)}

Compound (I) was found to be an extremely potent irreversible inhibitor of isomerase, whereas compounds (V) and (VI) did not inactivate the enzyme (Fig. 1). This is not surprising since the acetylene group is not activated for nucleophilic attack in the absence of the carbonyl group. The half-life of $2.0 \mu \mathrm{M}$-isomerase in the presence of 5-100 $\mu \mathrm{M}$-compound (I) ranged from $12 \mathrm{~min}$ to $45 \mathrm{~s}$ (Figs. $2 a$ and $2 b$ ). The inactivation event displayed saturation kinetics. Kitz-Wilson plots of the pseudofirst-order inactivation data gave a $K_{\mathrm{i}}$ of $66.0 \mu \mathrm{M}$ and a $k_{+2}$ of $12.5 \times 10^{-3} \mathrm{~s}^{-1}$ (Figs. $2 a$ and $2 b$ and Table 1). The term $k_{+2} / K_{1}$ describes the efficiency of the inhibitor and in this case was $188 \mathrm{M}^{-1} \cdot \mathrm{s}^{-1}$. Thus compound (I) appears to be three to four times more effective as an irreversible inhibitor than the corresponding enzyme-generated inhibitor derived from the acetylenic suicide substrate in the $\mathrm{C}_{18}$ series (compound $\mathrm{X}$ ), for which $k_{+2} / K_{\mathrm{1}}=50.9 \mathrm{M}^{-1} \cdot \mathrm{s}^{-1}$ as described by Robinson and his colleagues (Batzold 
\& Robinson, 1975; Covey \& Robinson, 1976). The powerful competitive inhibitor 19-nortestosterone retards the rate of inactivation by compound (I). In the presence of a constant concentration of $I(50 \mu \mathrm{M})$ and increasing concentrations of 19 -nortestosterone $(0-100 \mu \mathrm{M})$, the half-times of inactivation increased

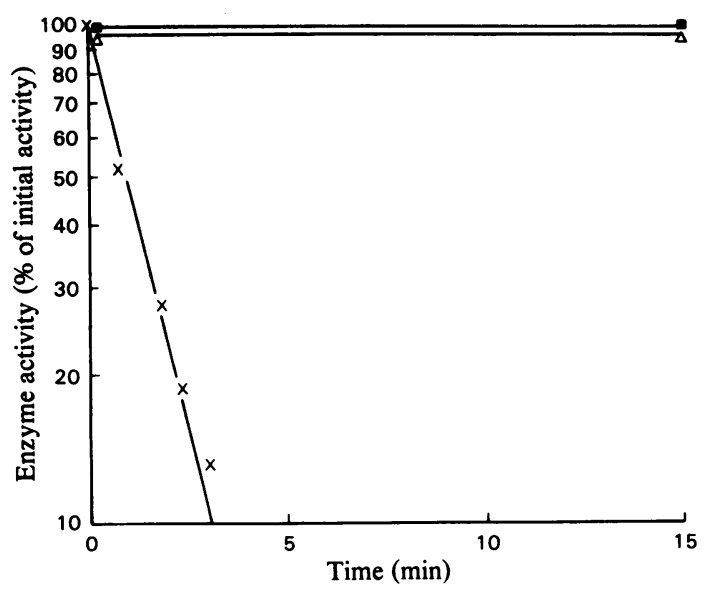

Fig. 1. Inactivation of $\Delta^{5}-3$-oxo steroid isomerase with 10ß-(1-oxoprop-2-ynyl)oestr-4-ene-3,17-dione (I) Isomerase $(2.0 \mu \mathrm{M})$ was incubated with either $100 \mu \mathrm{M}$-compound (I) (x), 200 $\mu \mathrm{M}-10 \beta-[(1 R)-1-$ hydroxyprop-2-ynyl]oestr-4-ene-3,17-dione (V) (D) or $200 \mu \mathrm{M}$-10 $\beta$-[ $(1 S)$-1-hydroxyprop-2-ynyl]oestr-4ene-3,17-dione (VI) $(\Delta)$, in $1 \mathrm{ml}$ of $1 \mathrm{~mm}$-potassium phosphate buffer, $\mathrm{pH} 7.0$, containing $4 \%$ (v/v) acetonitrile at $25^{\circ} \mathrm{C}$. Portions were removed at specified times and assayed for enzyme activity. 7-fold. Since the competitive inhibitor under steadystate conditions binds a constant fraction of enzyme as a reversible E-I complex, less enzyme is available for an affinity-labelling reagent that binds to the same site as 19-nortestosterone. It may be inferred that compound (I) is an active-site-directed inhibitor. A plot of the reciprocal of the first-order rate constant for inactivation with respect to 19nortestosterone concentration gave a $K_{1}$ value for 19-nortestosterone of $6.0 \mu \mathrm{M}$. This is comparable with the value of $12.8 \mu \mathrm{M}$ determined for 19 nortestostrone from direct competition studies in which the initial velocity of isomerization of a constant concentration of androst-5-ene-3,17-dione was measured in the presence of various concentrations of 19-nortestosterone (Table 1).

Incubation of $4.0 \mu \mathrm{M}$-isomerase with $5.0 \mu \mathrm{M}$ compound (I) leads eventually to $90 \%$ inactivation of the enzyme, suggesting that 1 molecule of inhibitor is incorporated per subunit of isomerase. Incubation of $4.0 \mu \mathrm{M}$-isomerase with excess compound (I) $(>10 \mu \mathrm{M})$ results in retention of less than $0.5 \%$ of the initial activity. If such preparations are left for 3 days at $25^{\circ} \mathrm{C}$, no recovery of enzyme activity is observed. Finally, the inactivated enzyme does not regain activity on dialysis. These findings suggest that compound (I) can cause a total inactivation of enzyme activity and that a stable covalent linkage is formed.

5,10-Seco-oestr-4-yne-3,10,17-trione (II) and $17 \beta$ hydroxy-5,10-seco-oestr-4-yne-3,10-dione (III)

Compounds (II) and (III) were found to be good irreversible inhibitors of $\Delta^{5}$-3-oxo steroid isomerase,
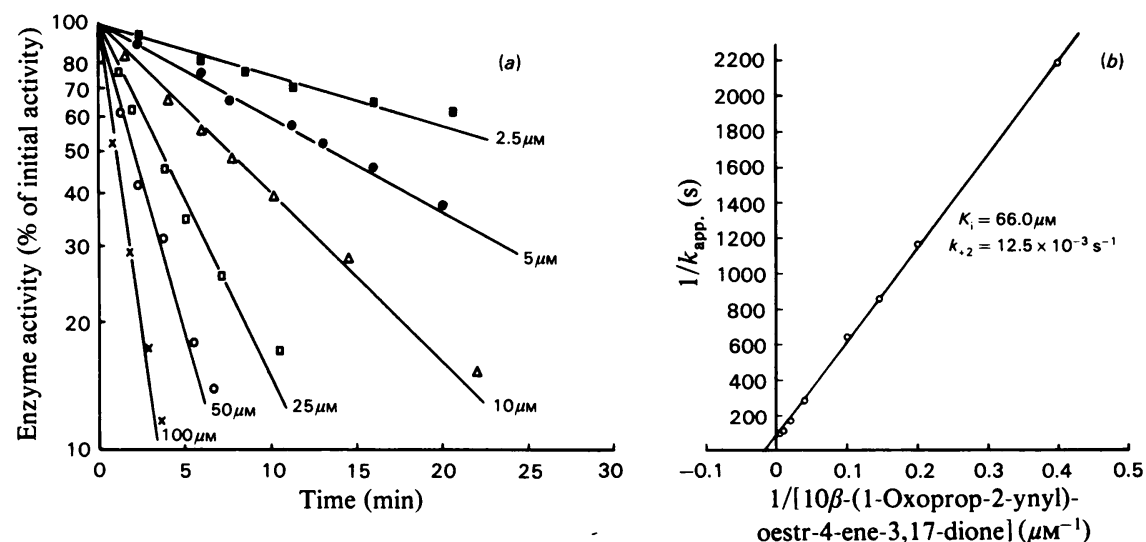

Fig. 2. Kinetics of inactivation of $\Delta^{5}$-3-oxo steroid isomerase with $10 \beta$-(1-oxoprop-2-ynyl)oestr-4-ene-3,17-dione (I) Isomerase $(2.0 \mu \mathrm{M})$ was incubated with variable concentrations of compound (I) as indicated, in $1 \mathrm{ml}$ of $1 \mathrm{~mm}$-potassium phosphate buffer, pH 7.0, containing $4 \%(\mathrm{v} / \mathrm{v})$ acetonitrile at $25^{\circ} \mathrm{C}$. Portions were removed at various times and assayed for enzyme activity. A semi-logarithmic plot of the percentage of enzyme activity remaining with respect to time was constructed as shown for each inhibitor concentration $(a)$. The resulting Kitz-Wilson plot (Kitz \& Wilson, 1962) from which the $K_{1}$ and $k_{+2}$ values were determined is shown (b). 
Table 1. Inactivation of $\Delta^{5}$-3-oxo steroid isomerase with active-site-directed acetylenic steroids $\Delta^{5}$-3-Oxo steroid isomerase $(2.0 \mu \mathrm{M})$ was incubated in $1 \mathrm{mM}$-potassium phosphate buffer, $\mathrm{pH} 7.0$, in the presence of compound (I) $(5-100 \mu \mathrm{M})$, compound (II) $(10-400 \mu \mathrm{M})$, compound (III) $(50-400 \mu \mathrm{M})$, compound (IV) $(2.5-20 \mu \mathrm{M})$, compound $(\mathrm{X})(20-400 \mu \mathrm{M})$ or compound $(\mathrm{XI})(10-400 \mu \mathrm{M})$. The inactivation results were analysed by Kitz-Wilson plots from which $K_{1}$ and $k_{+2}$ values were determined. Isomerase $(2.0 \mu \mathrm{M})$ was also incubated in the presence of a constant amount of compound (I) $(5.0 \mu \mathrm{M})$, compound (II) $(200 \mu \mathrm{M})$ or compound $(\mathrm{X})(50 \mu \mathrm{M})$ and the concentration of 19-nortestosterone was varied $(0-200 \mu \mathrm{M})$. From these protection experiments the $K_{1}$ values for 19-nortestosterone were determined (see the Materials and methods section). Experimental conditions A and B refer to the presence of either 4 or $8 \%$ by volume of acetonitrile respectively in the incubations. The acetonitrile concentration was increased to overcome the low solubility of some of the compounds. The $K_{1}$ values for 19-nortestosterone were also determined by competitive-inhibition studies performed in a $3 \mathrm{ml}$ reaction system containing $33 \mathrm{~mm}$-potassium phosphate buffer, $10 \mu \mathrm{l}$ of $1 \%$ bovine serum albumin and either 4 or $8 \%$ by volume of acetonitrile containing androst-5-ene-3,17-dione as substrate.

\begin{tabular}{|c|c|c|c|c|c|c|}
\hline \multirow[b]{3}{*}{$\begin{array}{l}\text { Experimental } \\
\text { conditions }\end{array}$} & \multirow[b]{2}{*}{ Inhibitor } & \multicolumn{3}{|c|}{$\begin{array}{l}\text { Kinetic constants } \\
\text { for inactivation }\end{array}$} & \multicolumn{2}{|c|}{$\begin{array}{l}A_{1} \text { values } \\
\text { obtained from: }\end{array}$} \\
\hline & & & & & Protection & Competitive-inhibition \\
\hline & Structure & $\begin{array}{c}K_{1} \\
\left(\mu_{M}\right)\end{array}$ & $\begin{array}{l}k_{+2} \\
\left(\mathrm{~s}^{-1}\right)\end{array}$ & $\begin{array}{c}k_{+2} / K_{1} \\
\left(\mathrm{M}^{-1} \cdot \mathrm{s}^{-1}\right)\end{array}$ & $\begin{array}{c}\text { studies } \\
(\mu \mathrm{M})\end{array}$ & $\begin{array}{c}\text { studies } \\
(\mu \mathrm{M})\end{array}$ \\
\hline
\end{tabular}

A

(I)

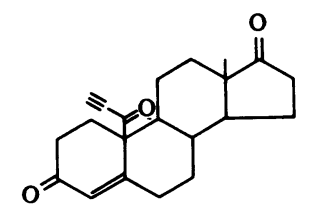

A

(X)<smiles>O=C1CC#CCC2C3CCC(=O)C34CCC(O)C2(CCC1)C4</smiles>

B

(II)<smiles>O=C1C#CCCC2C3CCC(=O)C34CCC(O)C24CCC1</smiles>

100.0

$3.02 \times 10^{-3}$

30.2

66.0

$12.5 \times 10^{-3}$

188

$52.0 \quad 2.65 \times 10^{-3}$

50.9<smiles>O=C1C#CCC2C(CCC3(O)C2CC[C@@H]3O)[C@H]1O</smiles>

166.0

B

(III)<smiles>O=C1CC#CCC2C(CCC34C(=O)CCC3C2C4O)C(=O)CC1</smiles>

(X)

B

66.0

$2.30 \times 10^{-3}$<smiles>CC#CCCC(=O)O</smiles>

(XI)

B

B

(IV)<smiles></smiles> 


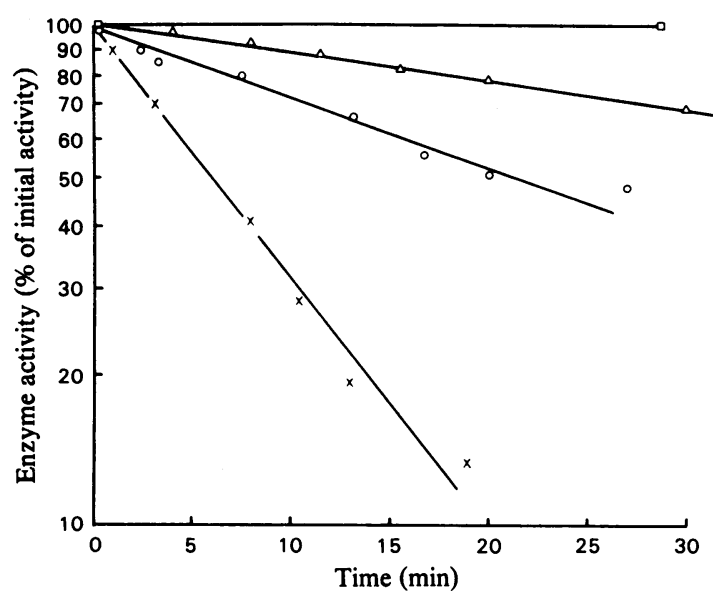

Fig. 3. Inactivation of $\Delta^{5}$-3-oxo steroid isomerase with 5,10-seco-oestr-4-yne-3,10,17-trione (II) and $17 \beta$ hydroxy-5,10-seco-oestr-4-yne-3,10-dione (III) Isomerase $(2.0 \mu \mathrm{M})$ was incubated with either $200 \mu \mathrm{M}$-compound (II) (X), $200 \mu \mathrm{M}$-compound (III) (O), $200 \mu \mathrm{M}$-compound (II) plus $200 \mu \mathrm{M}-19$ nortestosterone $(\triangle)$, or $200 \mu \mathrm{M}-3 \beta, 17 \beta$-dihydroxy5,10 -seco-oestr-4-yn-10-one (IX) ( $\square$ ), in $0.5 \mathrm{ml}$ of 1 mM-potassium phosphate buffer, pH7.0, containing $8 \%(\mathrm{v} / \mathrm{v})$ acetonitrile at $25^{\circ} \mathrm{C}$. Portions were removed at various time intervals and their enzyme activity was determined.

whereas the related $3 \beta, 17 \beta$-dihydroxy-5,10-secooestr-4-yne-10-one (IX) was without effect (Fig. 3). The half-lives with compound (II) $(10-400 \mu \mathrm{M})$ ranged from 40 to $5 \mathrm{~min}$, whereas those for compound (III) $(50-400 \mu \mathrm{M})$ ranged from 100 to $18 \mathrm{~min}$. The fact that compound (III) is a poorer inhibitor than compound (II) is borne out by the higher $K_{1}$ and lower $k_{+2}$ values (Table 1). Indeed the $k_{+2} / K_{1}$ ratio indicates that compound (II) is six to seven times more effective as an inhibitor than compound (III). The inactivation produced by (II) shows saturation kinetics and is retarded by 19 nortestosterone ( $K_{1}$ from competitive inhibition studies was $25.0 \mu \mathrm{M}$ ), suggesting that the process is active-site directed. When incubations are run overnight with $200 \mu \mathrm{M}$-compound (II) or -compound (III) less than $2 \%$ of the initial enzyme activity remains, and the enzyme does not regain activity after prolonged dialysis.

5,10-Seco-oestr-5-yne-3,10,17-trione (X) and 19nor-5,10-secopregn-5-yne-3,10,20-trione (XI) are suicide substrates of $\Delta^{5}$-3-oxo steroid isomerase (Batzold \& Robinson, 1975; Covey \& Robinson, 1976). Table 1 reports $K_{1}$ and $k_{+2}$ values obtained from Kitz-Wilson plots for the pseudo-first-order inactivations by these compounds. The values shown are measured under the conditions described in Table 1, and are comparable with those previously

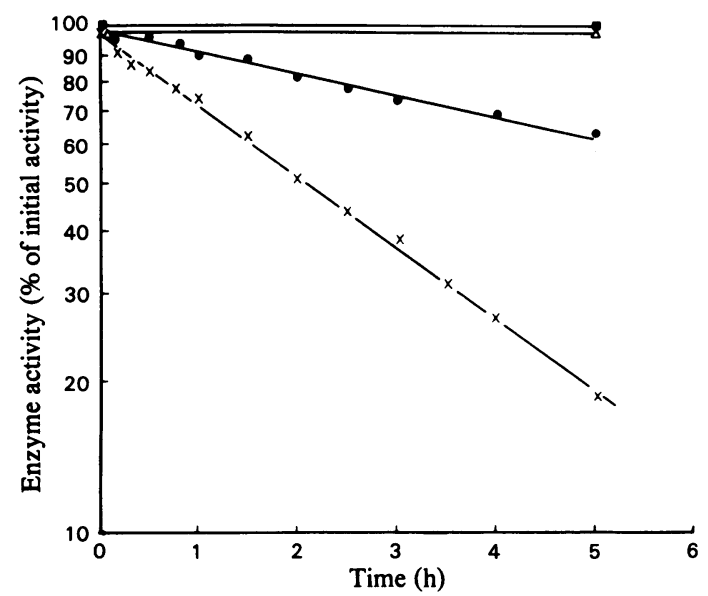

Fig. 4. Inactivation of $\Delta^{5}$-3-oxo steroid isomerase with 17 $\beta$-(1-oxoprop-2-ynyl)androst-4-en-3-one (IV) Isomerase $(2.0 \mu \mathrm{M})$ was incubated with either $20 \mu \mathrm{M}$ compound (IV) (x), $20 \mu \mathrm{M}$-compound (IV) plus $100 \mu \mathrm{M}$-19-nortestosterone (O), $20 \mu \mathrm{M}-17 \beta-[(1 S)-1$ hydroxyprop-2-ynyl]androst-4-en-3-one (VII) (囵, or $20 \mu \mathrm{M}-17 \beta-[(1 R)$-1-hydroxyprop-2-ynyl]androst4-en-3-one (VIII) $(\triangle)$, in $0.25 \mathrm{ml}$ of $1 \mathrm{~mm}$-potassium phosphate buffer, $\mathrm{pH} 7.0$, containing $8 \%$ (v/v) acetonitrile at $25^{\circ} \mathrm{C}$. Portions were removed at various times and assayed for enzyme activity.

reported (Batzold \& Robinson, 1975). Covey \& Robinson (1976) noted that the rates of isomerization of suicide substrates [compounds $(\mathrm{X})$ and (XI)] to enzyme-generated conjugated allenic ketones, the actual inactivators of isomerase, were very fast relative to the rates of inactivation seen with the allenic ketones. The similarity of the $k_{+2} / K_{1}$ ratios of 3.02 and 3.48 for compounds (II) and (X) respectively suggests that compound (II) and the conjugated allenic ketones derived from compound (X) are equally effective as affinity labels of isomerase.

\section{$17 \beta$-(1-Oxoprop-2-ynyl)androst-4-en-3-one (IV)}

Compound (IV) was found to be a relatively poor irreversible inhibitor of $\Delta^{5}$-3-oxo steroid isomerase from $P$. testosteroni and, as expected, the corresponding hydroxy compounds were not irreversible inhibitors (Fig. 4). Indeed the $K_{1}$ and $k_{+2}$ values obtained from Kitz-Wilson plots of pseudo-firstorder inactivation data show compound (IV) to be bound extremely tightly $\left(K_{1}=14.5 \mu \mathrm{M}\right)$ but very slow in alkylating $\left(k_{+2}=0.13 \times 10^{-3} \mathrm{~s}^{-1}\right)$, yielding a $k_{+2} / K_{1}$ ratio of $0.90 \mathrm{M}^{-1} \cdot \mathrm{s}^{-1}$ (Table 1). Protection can be afforded against inactivation with 19nortestosterone $\left(K_{1}=15 \mu \mathrm{M}\right)$, suggesting that the process is active-site directed. The covalent bond that forms is stable to dialysis. 


\section{Competitive-inhibition studies}

Compounds (V-IX) were found to be competitive inhibitors in initial-rate studies in which either androst-5-ene-3,17-dione or pregn-5-ene-3,20-dione was used as substrate. $K_{1}$ values obtained for these compounds (Table 2) were found to be the same with either substrate (endorsing the view that $\mathrm{C}_{19}$ - and $\mathrm{C}_{21}$-steroids are bound at the same steroidbinding site). Fig. 5 shows a typical family of Dixon plots for such competitive-inhibition studies. The inset shows a secondary plot of the slope of the Dixon plots with respect to $1 /[\mathrm{S}]$. The slope of this secondary plot yields the $K_{1}$.

In these studies $10 \beta-[(1 R)-1$-hydroxyprop-2-

Table 2. Competitive inhibition of $\Delta^{5}$-3-oxo steroid isomerase by acetylenic steroid analogues

The values for $V_{\max .}$ are approx. $50 \%$ of those observed under standard assay conditions [ $33 \mathrm{~mm}$-potassium phosphate of $\mathrm{pH} 7.0,1.67 \%(\mathrm{v} / \mathrm{v})$ methanol and $33 \mu \mathrm{g}$ of bovine serum albumin/ml]. The values reported were obtained in the presence of $6.7 \%(\mathrm{v} / \mathrm{v})$ acetonitrile. The nature and concentration of organic solvent profoundly affect the kinetic parameters of the reaction (Jones \& Wigfield, 1968; Falcoz-Kelly et al., 1968; Weintraub et al., 1977). Abbreviation used: N.D., not determined.

Kinetic constants for competitive inhibition with:

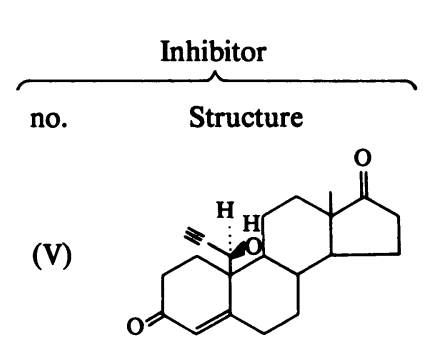

(VI)

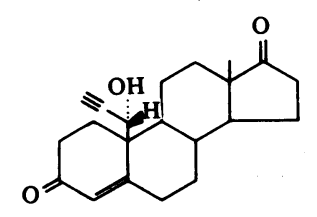
234<smiles>CC12CCC(O)=CC1CCC1C3CC[C@](C)(O)C3CCC12</smiles><smiles>C[C@H](O)[C@]12CCC3C4CCC5=CC(=O)CCC5(CCC43)C1CC2</smiles>

250

(VIII) $K_{\mathrm{m}}$
$(\mu \mathrm{M})$

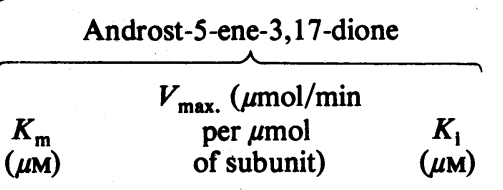

$1.54 \times 10^{6}$

81.0

$K_{\mathrm{m}}$ $(\mu \mathrm{M})$

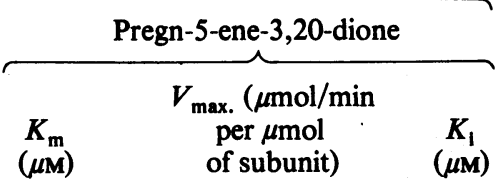

( $\mu \mathrm{M})$

(VII)

$$
2.49 \times 10^{6}
$$

27.0

8.0

$0.63 \times 10^{6}$

14.5

$0.7 \times 10^{6}$

140.0

$0.6 \times 10^{6}$

71.0

$1.65 \times 10^{6}$

165.0

8

.

.

$2.24 \times 10^{6}$

27.0

6.9

$0.588 \times 10^{6}$

25.0

(IX)<smiles>O=C1C2CCC3C(CC[C@@]4(O)C3CC[C@@H]4O)C2CCCC#C[C@@H]1O</smiles>

N.D.

N.D.

N.D.

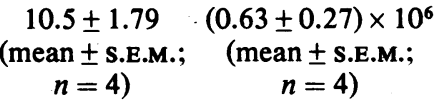




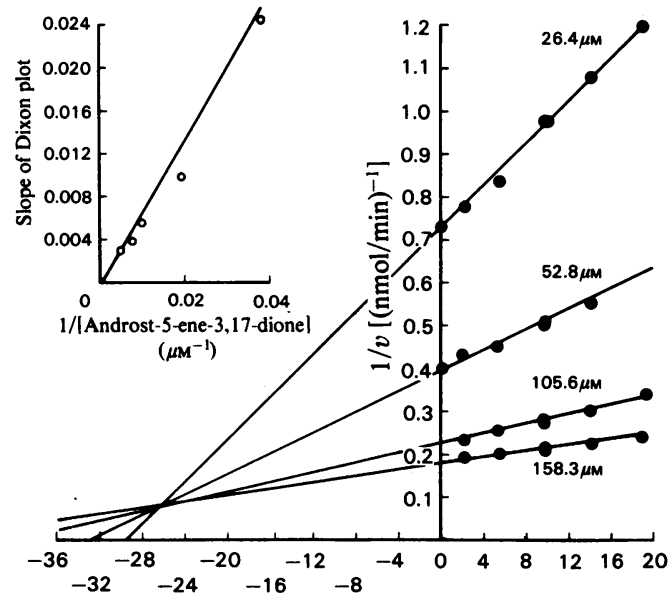

$17 \beta-[(1 S)$-1-Hydroxyprop-2-ynyl]androst-4-en-3-one concn. $(\mu \mathrm{M})$

Fig. 5. Competitive inhibition of initial rate of isomerization of androst-5-ene-3,17-dione by 17 $\beta-[(1 S)$ -

1-hydroxyprop-2-ynyllandrost-4-en-3-one (VII)

Initial rates of isomerization of fixed concentrations of androst-5-ene-3,17-dione (26.4, 52.8, 105.6 and $158.3 \mu \mathrm{M})$ were measured in the presence of variable concentrations of compound (VII) $(0-20 \mu \mathrm{M})$. Dixon plots were then constructed as shown. The inset shows a secondary plot of the slope of the Dixon plots with respect to $1 /[\mathrm{S}]$, from which the $K_{1}$ of the competitive inhibitor was calculated.

ynylloestr-4-ene-3,17-dione (V) was found consistently to be a better inhibitor than $10 \beta-[(1 S)$ 1-hydroxyprop-2-ynylloestr-4-ene-3,17-dione (VI). For example, $K_{1}$ values of $81 \mu \mathrm{M}$ and $165 \mu \mathrm{M}$ respectively were obtained with androst-5-ene-3,17dione as substrate and $K_{1}$ values of 71 and $140 \mu \mathrm{M}$ respectively with pregn-5-ene-3,20-dione as substrate.

Compounds (VII) and (VIII) appear to be equipotent as reversible inhibitors. In addition they bind fairly tightly to the enzyme with $K_{1}$ values between 25.0 and $33.0 \mu \mathrm{M}$ respectively (Table 2), as is normally the case with $\mathrm{C}_{21}$-steroids. This suggests that the enzyme has no preference as to whether the polar group at $\mathrm{C}-20$ is in the $\alpha$ - or $\beta$-configuration. Compound (IX) was found to be a very poor competitive inhibitor of isomerase $\left(K_{1}=346 \mu \mathrm{M}\right)$, indicating that when the acetylenic group occupies position- 4 in the seco-steroid a $3 \beta, 17 \beta$-diol is not well tolerated.

\section{Discussion}

After the pioneering studies of Bloch (1971), suicide substrates have been designed for use both in novel methods of affinity labelling and in selective approaches to drug design (Seiler et al., 1978). Many of the enzyme inactivators in this category are acetylenic compounds that are converted by their target enzymes into Michael acceptor systems. This activation may give rise to conjugated allenic ketones as described for compounds (X) and (XI) (Batzold \& Robinson, 1975; Covey \& Robinson, 1976), or to an allene conjugated with a Schiff's base, as in the case of the inactivation of pyridoxal phosphate-linked enzymes by propargylglycine (Abeles \& Walsh, 1973). Alternatively, the acetylene may be activated by direct conjugated with a Schiff's base, as in the case of the inactivation of $\gamma$ aminobutyric acid transaminase by 4-aminohex5-ynoic acid (Metcalf et al., 1978). However, little attention appears to have been accorded to the possibility of creating affinity-labelling reagents by introducing conjugated acetylenic ketone groupings into substrate analogues. The present paper describes four steroid analogues that contain such reactive groups and are active-site-directed irreversible inhibitors of $\Delta^{5}$-3-oxo steroid isomerase. We suggest that introduction of this functionality into substrates for enzymes requiring a base for their reaction mechanism could lead to new types of effective affinity-labelling reagents.

Of the compounds described in the present paper, compound (I) appears to be especially interesting, since it is one of the most potent irreversible inhibitors of $\Delta^{5}$-3-oxo steroid isomerase described. The presence of the bulky $10 \beta$-(1-oxoprop-2-ynyl) group was considered to be unfavourable for binding to the active site of the enzyme because of steric hindrance, since 19-nor-steroids (e.g. 19nortestosterone, $17 \beta$-oestradiol) are far more potent as reversible inhibitors of the enzyme than steroids carrying a 10-methyl substituent (Wang et al., 1963; Weintraub et al., 1977). This conclusion may require revision in the light of the finding that $10 \beta-(1-$ oxoprop-2-ynyl) groups and 10-oxo substituents are associated with relatively low $K_{\mathrm{i}}$ values, in comparison with those obtained for 19-methyl steroids. Thus, the chemical nature rather than the presence of a substituent at C-10 may be a far more important factor in controlling the binding of the steroid analogue. It has been suggested on the basis of crystallographic studies of isomerase substrates and suicide inhibitors (Carrell et al., 1978) that the intramolecular transfer of the $4 \beta$-proton to the $6 \beta$-position that occurs during the isomerization reaction may be mediated by a basic residue that is symmetrically located with respect to the $4 \beta$-proton and the 19-methyl group. The potent inactivation of isomerase by compound (I) suggests that the space occupied by the 10 $\beta$-(1-oxoprop-2-ynyl) Michael acceptor system may be located close to this important nucleophile that abstracts the $4 \beta$-proton (Scheme 3). 

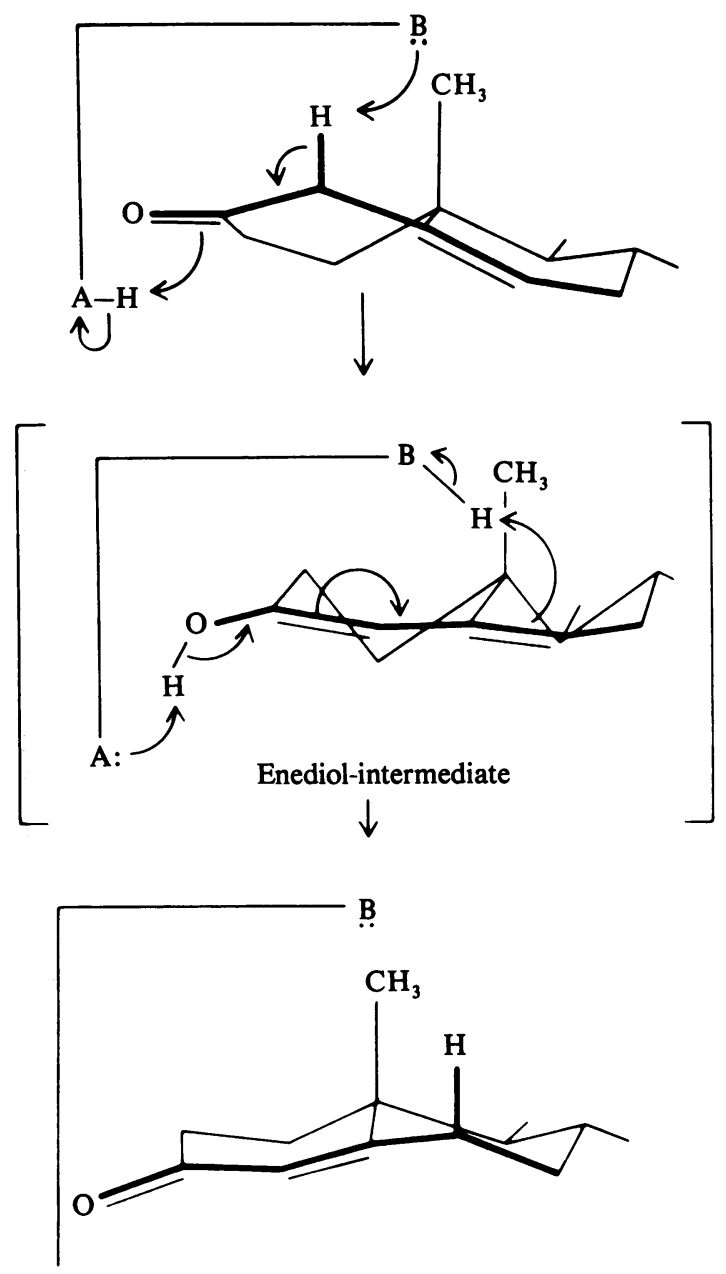

A-H

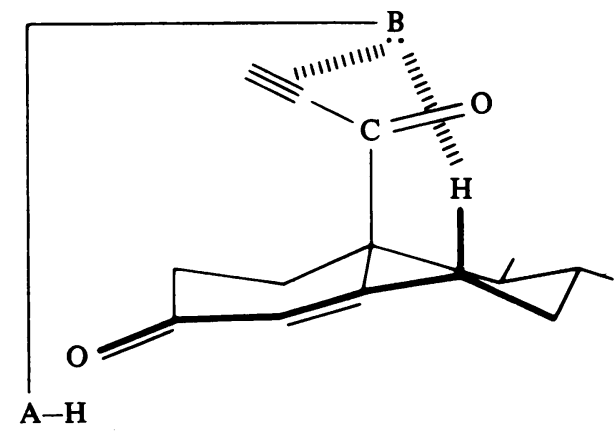

Scheme 3. Mechanistic pathway for enzyme-catalysed isomerization of $\Delta^{5}$-3-oxo steroids to $\Delta^{4}-3$-oxo steroids based on the $X$-ray crystallographic structure for androst-5-ene-3,17-dione

The isomerization reaction is facilitated by an acid (AH) and a base (B) at the active site. The base (B) abstracts the $4 \beta$-proton. The crystallographic structure of androst-5-ene-3,17-dione clearly indicates that this base must be positioned above the plane of the A-ring of the steroid and is symmetrically located with respect to both the $4 \beta$-proton and the 19 -methyl group. The planar $\Delta^{3,5}$-dienol is an intermediate and the $4 \beta$-proton is subsequently transferred intramolecularly to the $6 \beta$-position to give the $\Delta^{4}$-3-oxo steroid. A structure for the 10 $\beta$-(1) oxoprop-2-ynyl)androst-4-ene-3,17-dione is shown (lower right) in which the $\alpha, \beta$-acetylenic ketone substituent is in close proximity to the base (B). This could explain the inhibitory potency of this compound.

Another surprising finding is that compound (II) (containing the 17-oxo group) is about six to seven times more potent as an alkylating agent than compound (III) (containing the $17 \beta$-hydroxy group). In contrast, there is little difference in the $K_{1}$ values for androst-4-ene-3,17-dione $(200 \mu \mathrm{M})$ and testosterone $(150 \mu \mathrm{M})$ (Weintraub et al., 1977). We conclude that the changes in the conformation of the A/B ring system, resulting from removal of the 5,10 bond and the introduction of an acetylenic linkage, may affect the spatial position of the $D$ ring and place the $17 \beta$-hydroxy group of compound (III) in an unfavourable (hydrophobic) environment. That the conformation of the A ring can affect the topographic position of the D ring and influence binding affinities is also suggested by the studies of Weintraub et al. (1977), who have shown that oestra-1,3,5-triene derivatives (with planar A rings) carrying $17 \alpha$-acetylenic substituents are bound very efficiently to the enzyme, whereas the analogous 
androstene derivatives with $17 \alpha$-acetylenic groups are not well tolerated. The interactions near position17 of the steroid are further emphasized by the findings that steroids bearing a hydroxypropynyl group at C-17 are good reversible inhibitors of the isomerase, irrespective of the configuration of the hydroxy group at C-20 ( $K_{1}$ values of $\left.25-33 \mu \mathrm{M}\right)$ for compounds (VII) and (VIII). This behaviour would appear to be in marked contrast with the already described large differences in the inhibitory potency of $17 \alpha$-hydroxyandrost-4-en-3-one, which is not bound, versus 17 $\beta$-hydroxyandrost-4-en-3-one (testosterone), which has a $K_{1}$ value of $150 \mu \mathrm{M}$ (Weintraub et al., 1977). These values were determined in the presence of $10 \%(\mathrm{w} / \mathrm{v})$ methanol as co-solvent, whereas the kinetic parameters reported in Table 2 were measured in $6.7 \%(\mathrm{w} / \mathrm{v})$ acetonitrile. Despite the profound effects of organic solvents on kinetic parameters of the isomerization reaction (Jones \& Wigfield, 1968; Falcoz-Kelly et al., 1968; Weintraub et al., 1977) we believe these comparisons to be sound. The hydroxy groups of $17 \beta$-hydroxypropynyl substituents could rotate so that they lie outside the influence of any unfavourable interactions with the enzyme surface.

These studies were supported by Research Grants AM 07422 and CA 23582 from the National Institutes of Health, Bethesda, MD, U.S.A.

\section{References}

Abeles, R. \& Walsh, C. T. (1973) J. Am. Chem. Soc. 95, 6124

Batzold, F. H. \& Robinson, C. H. (1975) J. Am. Chem. Soc. 97, 2576-2578

Batzold, F. H. \& Robinson, C. H. (1976) J. Org. Chem. 41, 313-317

Benson, A. M., Jarabak, R. \& Talalay, P. (1971) J. Biol. Chem. 246, 7514-7525

Benson, A. M., Suruda, A. J., Shaw, R. \& Talalay, P. (1974) Biochim. Biophys. Acta 348, 317-320

Benson, A. M., Suruda, A. J. \& Talalay, P. (1975) J. Biol. Chem. 250, 270-280

Bloch, K. (1971) Enzymes 3rd Ed. 5, 441-464

Brocklehurst, K. (1979) Biochem. J. 181, 775-778

Büki, K. G., Robinson, C. H. \& Talalay, P. (1971) Biochim. Biophys. Acta 242, 268-277
Carrell, H. L., Glusker, J. P., Covey, D. F., Batzold, F. H. \& Robinson, C. H. (1978) J. Am. Chem. Soc. 100, 4282-4289

Covey, D. F. (1979) Steroids 34, 199-206

Covey, D. F. \& Robinson, C. H. (1976) J. Am. Chem. Soc. 98, 5038-5040

Covey, D. F., Albert, K. A. \& Robinson, C. H. (1979a) J. Chem. Soc. Chem. Commun. 795-796

Covey, D. F., Parikh, V. D. \& Chien, W. W. (1979b) Tetrahedron Lett. 23, 2105-2108

Dixon, M. (1953) Biochem. J. 55, 170-171

Falcoz-Kelly, F., Baulieu, E.-E. \& Alfsen, A. (1968) Biochemistry 7, 4119-4125

Jarabak, R., Colvin, O. M., Moolgavkar, S. H. \& Talalay, P. (1969) Methods Enzymol. 15, 642-651

Jones, B. J. \& Wigfield, D. C. (1968) Can. J. Chem. 46, $1459-1465$

Kawahara, F. S. (1962) Methods Enzymol. 5, 527-532

Kawahara, F. S. \& Talalay, P. (1960) J. Biol. Chem. 235, PC 1-2

Kawahara, F. S., Wang, S.-F. \& Talalay, P. (1962) J. Biol. Chem. 237, 1500-1506

Kitz, R. J. \& Wilson, I. B. (1962) J. Biol. Chem. 237, 3245-3249

Lineweaver, H. \& Burk, D. (1934) J. Am. Chem. Soc. 56, 658-666

Malhotra, S. K. \& Ringold, H. J. (1965) J. Am. Chem. Soc. 87, 3228-3236

Metcalf, B., Lippert, B. \& Casara, P. (1978) in EnzymeActivated Irreversible Inhibitors (Seiler, N., Jung, M. J. \& Koch-Weser, J., eds.), pp. 123-133, Elsevier/ North-Holland Biomedical Press, Amsterdam, New York and Oxford

Ogez, J. R., Tivol, W. F. \& Benisek, W. F. (1977) J. Biol. Chem. 252, 6151-6155

Pollack, R. M., Kayser, R. H. \& Bevins, C. L. (1979) Biochem. Biophys. Res. Commun. 91, 783-790

Seiler, N., Jung, M. J. \& Koch-Weser, J. (1978) Enzyme-Activated Irreversible Inhibitors, Elsevier/ North-Holland Biomedical Press, Amsterdam, New York and Oxford

Talalay, P. \& Benson, A. M. (1972) Enzymes 3rd Ed. 6, 591-618

Wang, S.-F., Kawahara, F. S. \& Talalay, P. (1963) $J$. Biol. Chem. 238, 576-585

Weintraub, H., Vincent, F., Baulieu, E.-E. \& Alfsen, A. (1977) Biochemistry 16, 5045-5053

Westbrook, E. M. (1976) J. Mol. Biol. 103, 659-664

Westbrook, E. M., Sigler, P. B., Berman, H., Glusker, J. P., Bunick, G., Benson, A. M. \& Talalay, P. (1976) J. Mol. Biol. 103, 665-667 